\title{
Multilingualism in Modern Kazakhstan: New Challenges
}

\author{
Bibigul Yergaliyevna Yeskeldiyeva ${ }^{1} \&$ Saule Zhaksylykbaevna Tazhibayeva ${ }^{1}$ \\ ${ }^{1}$ L. N. Gumilyov Eurasian National University, Astana, Kazakhstan \\ Correspondence: Bibigul Yergaliyevna Yeskeldiyeva, L. N. Gumilyov Eurasian National University, Mirzoyan \\ str., 2, Astana, 010008, Kazakhstan. E-mail: bibigul05@mail.ru; sauletazhibayeva@mail.ru
}

Received: October 3, 2014 Accepted: November 14, 2014 Online Published: February 25, 2015

doi:10.5539/ass.v11n6p56

URL: http://dx.doi.org/10.5539/ass.v11n6p56

\begin{abstract}
The paper is devoted to the problem of multilingualism and multilingual education in modern Kazakhstan.

Kazakhstan is a multiethnic and multi-religious state, where live more than 126 representatives of different ethnic groups. At the present stage in the development of Kazakhstani society, bilingualism is gradually turning into multilingualism. One of the most important strategic goals of the language policy of Kazakhstan is the necessity of speaking several languages: Kazakh, Russian and English. Kazakhstan is currently implementing overall modernization of the education system and embedding a multilingualism policy into the educational process as well. The experimental sites for multilingual education have been initiated in several Kazakhstani Universities and secondary schools. The young Kazakhstani generation brought up in independent Kazakhstan is involved in multilingual education process. By the year 2020, $100 \%$ of the population is expected to speak the Kazakh language, 95\% Russian and 25\% English. For the implementation of these goals a fundamentally new type of learning - e-learning - is being developed. Its test-project has been initiated within 44 institutions. In 2014 the Ministry of Education and Science of the Republic of Kazakhstan is increasing the number of such institutions by providing them with the Internet access at the speed of 4 to $10 \mathrm{Mbit}$ per sec. The outcome of the research is based on the sociolinguistic data which has been conducted in all regions of the country, using the methods of sociolinguistic data collection.
\end{abstract}

Keywords: Kazakhstan, bilingualism, multilingualism, multilingualism policy, multilingual education, multilingual education process, e-learning

\section{Introduction}

Kazakhstan is an independent democratic state, which is situated on the border of two continents - Europe and Asia. Kazakhstan is one of the most sparsely populated countries in the world with 5.5 persons per $1 \mathrm{sq} . \mathrm{km}$; however it covers the vast territory. The state language is Kazakh. Russian language is the language of multicultural communication.

Kazakhstan is a polyethnic country. It has ethnic and confessional variety, cultural diversity.

\subsection{Kazakhstan in the Soviet Period}

In the Soviet Period Kazakhstan became a multiethnic government. It was called a "laboratory of friendship". Kazakhstan was a kind of mosaic of ethnicities after J. Stalin enacted a policy of internal deportation and resettlement. Different ethnicities as Chechens, Koreans, Germans, Meskhetian Turks, Crimean Tatars, Karachais, Balkars, Kumyks, Kurds, Russian political prisoners, Poles and many other groups were forcibly exiled to Kazakhstan. During the Soviet period the Republic of Kazakhstan underwent tremendous demographic shifts. Kazakhs became a minority in their native territory and the Kazakh language lost its position. The Kazakh language and Kazakh culture were neither dominant nor venerated. However, it remained the state language of the Kazakh Soviet Socialist Republic. Russian was the language of interethnic communication and it had a strong influence on social and cultural life. The majority of Kazakhs was fluent in Russian. The younger generation began to forget their native language. There were only a few Kazakh schools in the republic with Kazakh language program. The Russian language dominated in almost all spheres of life, while the Kazakh language was driven to the social margins.

\subsection{Kazakhstan in the Period of Its Independence}

Since the dissolution of the Soviet Union (1991) the language situation changed. According to 1999 census of 
the Republic of Kazakhstan, ethnic Russians, who had gotten political and cultural dominance during the Soviet years, about two million have left Kazakhstan since 1991. Population of ethnic Ukrainians have declined by over 3\% since 1989. Ethnic Germans - descendants of Germans deported from the Volga German Autonomous Republic - at one time formed 7.1 percent of the total population of present-day Kazakhstan. Since independence, however, the majority have resettled in Germany under liberal immigration laws. Today, the country's principal small ethnic groups include Russians (23.7\% of the population), Uzbeks (2.8\%), Ukrainians (2.1\%), Uighurs (1.4\%), Tatars (1.3\%), and Germans (1.1\%) (Agenstvo Respubliki Kazakhstan po statistike (ARK), 2000).

Kazakhs have retained the majority and the Kazakh language became the state language of Kazakhstan, Russian remained the language of interethnic communication. However, Russian is prevailing over Kazakh in many aspects of social and cultural life. Sociolinguistic situation and Kazakhstani language policy from different perspectives was comprehensively studied by Henryk Jankowski. He observed spoken Kazakh language contacts, code-mixing and code-switching (Jankowski, 2012).

\subsection{Influence of Social Problems on Education}

After the disintegration of the Union of Soviet Socialist Republics (USSR) in 1991, Kazakhstan experienced a lot of social problems due to the collapsed economy, all of which had a negative impact on education.

The government made an attempt to redesign the content and form of Kazakhstani educational system. Two or three institutes of different types were united into one university. These changes were the most painful for Pedagogical (Teacher Training) Institutes. It also greatly affected the pupils' acquisition of knowledge. The poor effect on pupils' knowledge made the Ministry of Education to rethink these changes. It decided to separate the Pedagogical Institutes from the universities and to support them more than universities. By the resolution of the Government of Kazakhstan on February $3^{\text {rd }} 2004$ 'the pedagogical Institutes were separated from the universities and acquired the status of State Pedagogical Institutes' (The resolution of the Government of Kazakhstan, 2004). Though the literacy rate of the country is rather high - 97\%, the government is giving thought to improving and making the Kazakhstan's educational system competitive. The way out of the problem is considered to be the implementation of multilingual education (Poslanie Prezidenta Respubliki Kazakhstan N. Nazarbaeva, 2012).

In order to do this, the teachers of Kazakhstan need to be well trained. The changing demands of the time make it imperative that a new and upgraded system of teacher training be evolved. Teachers are faced with new requirements: how to be multilingual and become aware of new technologies. Learning about the world experience of multilingual education became the urgent task.

\subsection{Research Questions}

Studies of the situation in multilingual education show that a range of consistent actions should be made, namely:

- Study of the real situation with regard to multilingual education in the Republic of Kazakhstan (RK);

- Research the questions of language preference among undergraduates and school students;

- Outline the problems undergraduates and secondary school students come across in gaining multilingual education;

- Research the effective ways of implementing multilingual education.

\section{Methodology of Sociolinguistic Research}

With regard to the above mentioned matters multilingual education in schools and universities of the Republic of Kazakhstan has been studied to clear up the real situation in RK.

The goal of the sociolinguistic research is to gain an understanding of the attitudes of school and undergraduates concerning the development of a multilingual education environment in RK. The experimental sites for multilingual education have been several Kazakhstani Universities and secondary schools. Young Kazakhstani generation brought up in independent Kazakhstan is involved in multilingual education process.

The questionnaires have been worked out by the authors of the paper that include seven items:

1) General Information;

2) Level of teaching languages: Kazakh, Russian and English;

3) Methods of teaching;

4) Language proficiency;

5) Choice of disciplines for multilingual education; 
6) Quality of teaching languages;

7) E-learning

Research target: school students and undergraduates of Kazakhstan.

Geography of research: cities: Almaty, Astana, Uralsk, Semei, Taraz.

Informational base of research: data received from questionnaires of sociolinguistic research, which was held among school students and undergraduates during September-October 2013.

In this paper we are going to discuss the problems of language situation in modern Kazakhstan and consider the questions concerning the level of teaching Kazakh, Russian and English in institutions; language proficiency, quality of teaching languages and effectiveness of modern technologies in educational process.

As we have already mentioned the language situation in modern Kazakhstan differed greatly from that in the Soviet period in the following: firstly, the spheres of Kazakh and Russian language usage were not incompatible; secondly, language contacts of Russian and Kazakh were not intersected. Russian speaking population (Russians and Russified Kazakhs) lived in the urban areas. While indigenous Kazakhs (Kazakh monolinguals) lived mostly in the rural areas or in the small provincial towns. Such situation differed with respect to the areas (e.g. North and East parts of Kazakhstan; South and West parts of Kazakhstan). Kazakh and Russian population existed in two parallel worlds which were not greatly intersected. This is the main reason that Kazakh and Russian worlds coexisted without any conflicts. In modern period the situation has changed in both directions. It is absolutely for the Kazakh Russified speakers to learn the Kazakh language.

Since Russian is fairly widespread, the problem is reduced to the need to master the state language. Twenty three years passed after the Soviet period, but the Kazakh language is still not dominant. However, we should stress that spheres of its usage broadened in

1) the educational process of Kazakhstani higher and secondary education;

2) the mass media and Kazakh journalistic.

The role of Kazakh mass media achieved much progress and promoted to the cultural development of the country. As the result the Kazakh world became more sufficient than it was in the Soviet period.

Another reason for the positive changes in the Kazakh language status is the increasing process of internal migration, which is mainly connected with the migration of the Kazakh speaking Kazakh population (especially young people) from rural areas to big cities.

Kazakh and Russian worlds are not parallel in the contemporary time. In this connection there appeared some "hot points" in social and cultural interaction.

There is one more important aspect - at present a number of young Kazakh people who has grown up in the era of Independence of Kazakhstan has increased both in rural and urban areas. They graduated from secondary schools and high educational institutions that have their educational programs in the Kazakh language.

The young Kazakhstani generation has serious social expectations with respect to language policy. They painfully react to the fact that the generation of their parents do not speak and even do not understand their native tongue. This is a serious problem in modern society.

The state language of the country is Kazakh; it is de facto and de jure. However it should be restored not only among the Russified urban Kazakhs and they should not use it only for communicative sense but they should think in their native tongue. It is the civic duty of all Kazakhstani citizens to master the state language.

Much attention should be also paid to the cultural aspects of Russified Kazakhs and their involvement in cultural life on the state language. For this purpose the Kazakh language should not be artificial language on the contrary it should become the natural language of culture.

It is important to implement multilingual education in Kazakhstan that should promote professional development of the teachers, academic staff and make Kazakhstani education competitive. With this respect a special sociolinguistic research has been conducted. Undergraduates and secondary school students were involved in the questionnaire. The percentage of males among undergraduates equals $36.4 \%$ and among school students $50 \%$; the percentage of females among undergraduates is $63.6 \%$ and among school students $50 \%$. The ethnicity statistics are the following: 


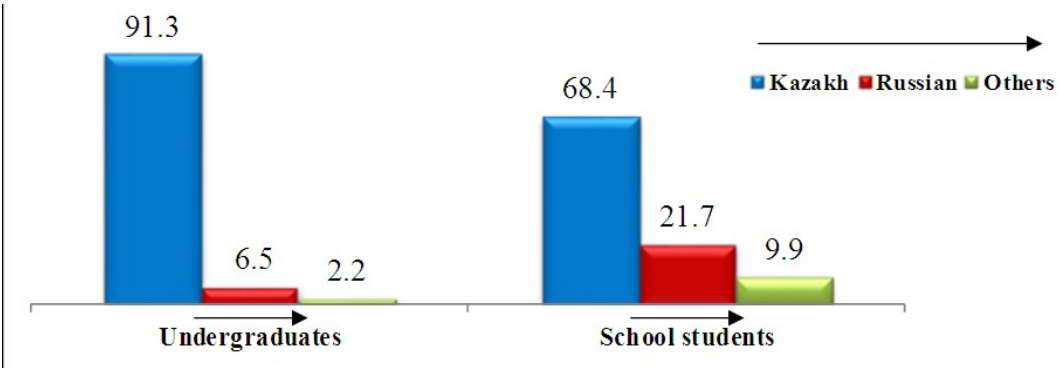

Figure 1. Distribution of respondents by ethnicity

\section{World Experience in Multilingual Education}

World practice of studying issues of multilingualism has been researched by foreign researchers (Parsons, 1975; Edwards, 1994; Stern, 1995; Bennet, 1998; Caldwell, 2010; Meyer \& Apfelbaum, 2010; McLeod \& Goldstein, 2012; Arzoz, 2012).

Multilinguism is also regarded by United Nations Educational, Scientific, and Cultural Organization (UNESCO, 2003). The American Association of psychologists has been carrying out research on cognitive abilities in pedagogy (García \& Náñez, 2011).

Different approaches can be found in the works of Russian and Kazakhstani scholars as well (Kopylenko, 1997; Janpeisova, 2006; Amalbekova, 2009; Jikeyeva, 2011) stressing different aspects.

The role of the Kazakh language in Kazakhstani education with respect to urban schools was investigated by the American scholar, who drew out acute problems of language balance in Kazakhstan with respect to urban schools as cultural and education elite prevail in the big cities (Fierman, 2006).

\subsection{Issues Concerning Kazakhstani Educational Modernization}

The Republic of Kazakhstan has realized a dramatic modernization of its education system by actively introducing a multilingualism policy in its educational process. Only a few of the Commonwealth of Independent States (CIS) countries have developed multilingualism at the national level. Most of the post-soviet republics with forcibly instituted bilingualism have turned their language policies to multilingualism. In Kazakhstan multilingualism is being developed at the national level in accordance with tasks that have been established by the President of RK' N. A. Nazarbayev (Poslanie Prezidenta Respubliki Kazakhstan N. Nazarbaeva, 2012). The initiative of what the head of the state has entitled "The Trinity of languages" is being realized. Multilingualism, as a strategically important task, is supported also by the National Program for the Development of Education 2011-2020 (Gosudarstvennaja programma razvitija tehnicheskogo i professional'nogo obrazovanija v Respublike, 2010).

Internationally, issues connected with the questions of multilingualism and multilingual educations are being thoroughly studied. UNESCO gives the highest priority to multilingual education (UNESCO, 2003). The American Psychological Association conducts special research on cognitive abilities of multilingualism in education. Issues of multilingualism, education and culture have been considered at the meetings of the Commission of the European Communities on a yearly basis since 2007 (Commission of the European Communities, 2007). Moreover, the European Commission allocates grants for research on multilingualism with the adaptation of e-learning tools (Babylon \& ONtology: Multilingual and cognitive e-Learning Management System via PDA phone, 2009).

\section{Results of Sociolinguistic Research}

\subsection{Multilingualism in Kazakhstan: Preconditions and Circumstances}

In the academic year 2013-2014 multilingualism is being placed into education process in a pilot mode at 35 schools. It is expected that teaching will be conducted in Russian, Kazakh and English. The subjects of mathematical and natural sciences will mainly be taught in English. It is planned that English learning will be started from grade 1 and even in preschool education.

The data of the conducted sociolinguistic research reveal the following. 


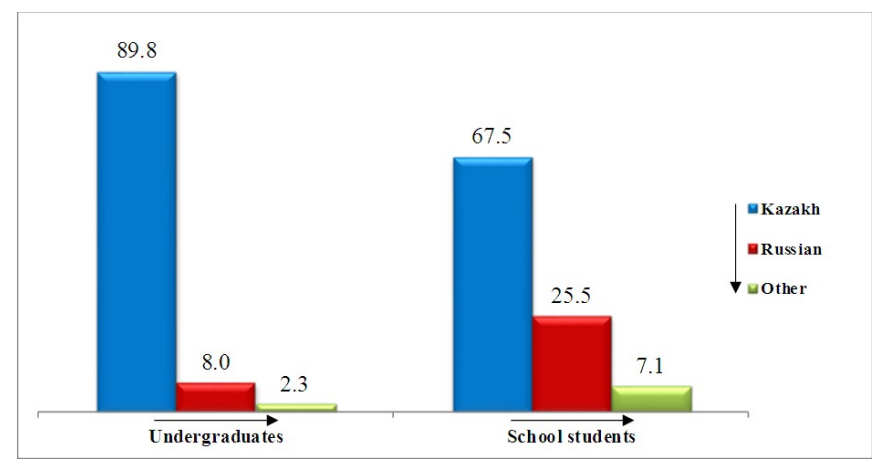

Figure 2. Distribution of the respondents' answers to the question: "What is your mother language?"

The majority of respondents both among undergraduates and school students take Kazakh as their mother language. Comparison with the date on respondents' ethnicity allows us to state that the Kazakhstani young generation admits the language of their ethnicity as a mother language. Herewith, as it shows on Figure 3, the knowledge of Russian among Kazakhstani youth is rather high. As for proficiency of English, it is rather low in comparison with Russian.

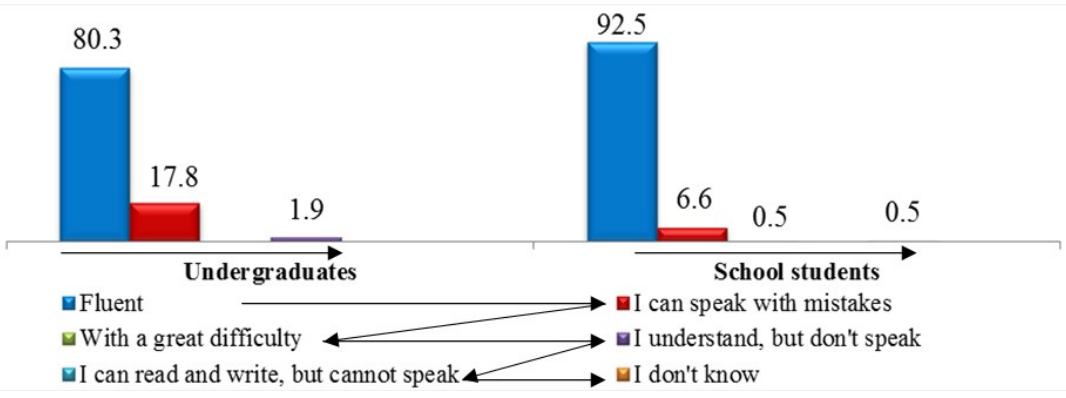

Figure 3. Distribution of the respondents' answers to the question: "How do you evaluate the level of your Russian language knowledge?"

The majority of undergraduates and schools students have a good command of Russian $(80.3 \%$ of undergraduates and $92.5 \%$ school students respectively).

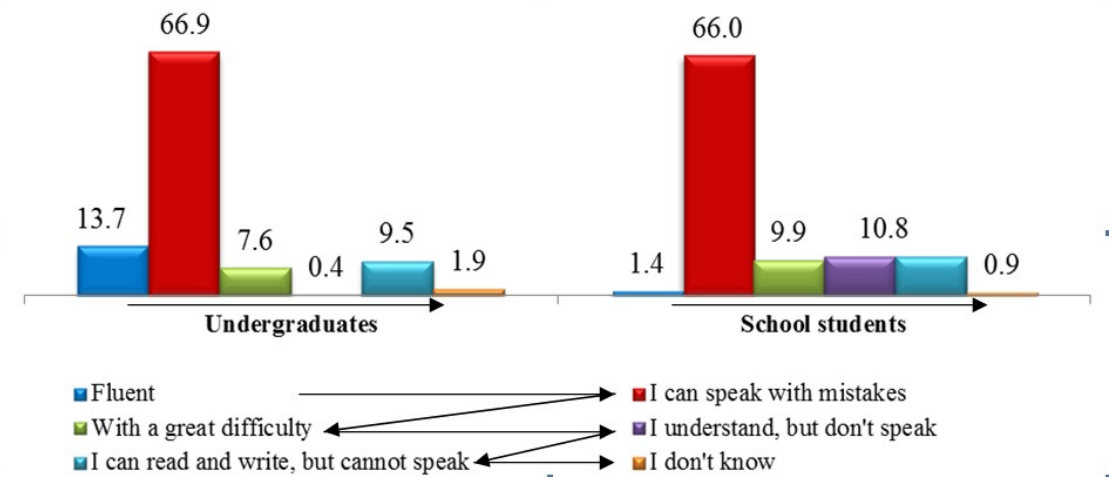

Figure 4. Distribution of the respondents' answers to the question: "How do you evaluate the level of your English language knowledge?"

Undergraduates and secondary school students are very critical regarding their knowledge of English (Figure 4). Kazakhstan changed its educational policy towards the implementation of new technologies in the educational 
process for improvement of language proficiency (Kubeev et al., 2008).

So, for young Kazakhstani generation, multilingual education is important. Knowledge of languages has its evident advantages as it is a beneficial investment in human capital.

\subsection{The Quality of Teaching English in Kazakhstan}

Undergraduates and secondary school students note that studying English at school and at universities has helped them to speak English fluently. However, there are a few among them who were not satisfied by their level of English, and they noted that it was not "helpful (Figure 5).

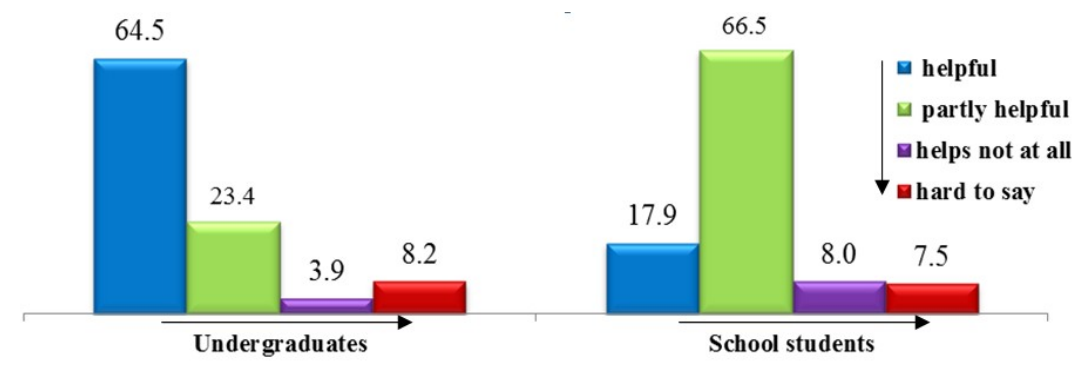

Figure 5. Distribution of the respondents' answers to the question: "How has learning English at school and at university helped you to master English?"

Undergraduates and secondary school students explain the low level of their English skills by the reasons outlined in Figure 6.

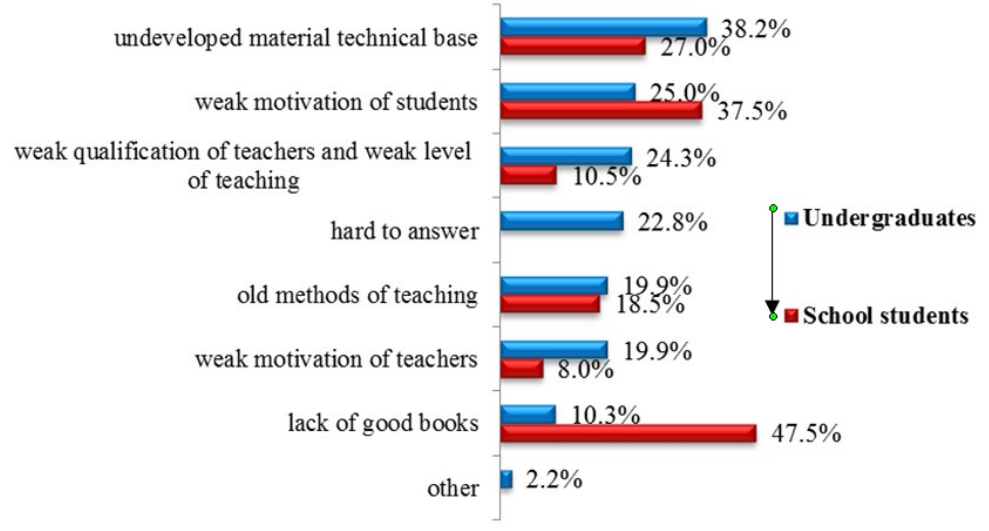

Figure 6. Distribution of the respondents' answers to the question: "What do you connect the reason of the low level of their English skills with?"

Both groups of respondents explain their poor language proficiency by the following:

- old technical base;

- weak motivation of students;

-weak qualification of teachers;

- the usage of old methodology;

-the lack of good textbooks

-the low level of motivation.

Ministry of Education of the Republic of Kazakhstan is making attempts to change the situation for better. It is promoting a special program for professional development due to new challenges and demands of society (Ministry of Education of the Republic of Kazakhstan, 2010). 


\subsection{Language Preference of Young Kazakhstani Generation}

Kazakhstani youth both undergraduates and school students approve of the development of multilingual education in the country: this is shown in the statistics presented in Figure7. Most undergraduates and school students stand for multilingual education. Most students responded to the question "Would you like to take classes only in Kazakh?" by saying that they would like to be taught in three languages: Kazakh, Russian and English (Figure 7).

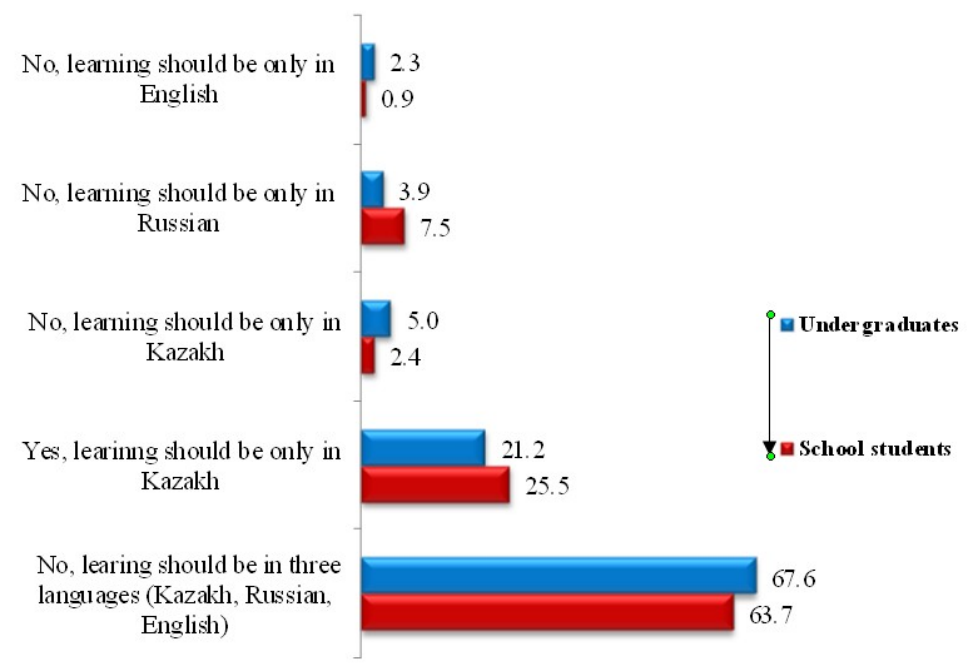

Figure 7. "Would you like to take classes only in Kazakh?" by saying that they would like to be taught in three languages: Kazakh, Russian and English

It should be stressed, that English is becoming popular among young Kazakhstani undergraduates and secondary school students. They would like to be taught in three languages: Kazakh, Russian and English.

\section{The Popularity of E-learning (Electronic Learning) in Kazakhstan}

E-Learning is a system of learning by means of electronic and information technologies.

E-learning offers a great opportunity for gaining sufficient knowledge. Kazakhstani young generation, as their peers around the world, live in the world of highly developed technology. That is why $83 \%$ of undergraduates and $59 \%$ of secondary school students would like to learn English, Kazakh and Russian by means of electronic technologies.

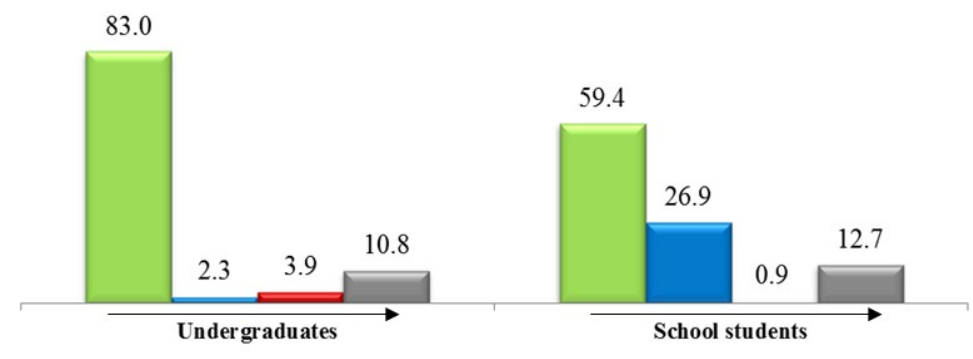

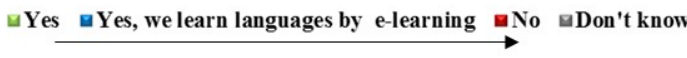

Figure 8. Distribution of the respondents' answers to the question: "Would you like to learn English, Kazakh and Russian by means of e-learning?"

English is a very popular language among Kazakhstani youth, especially among the university students. More than half of them think that they can be successfully trained in English with a help of e-learning. 


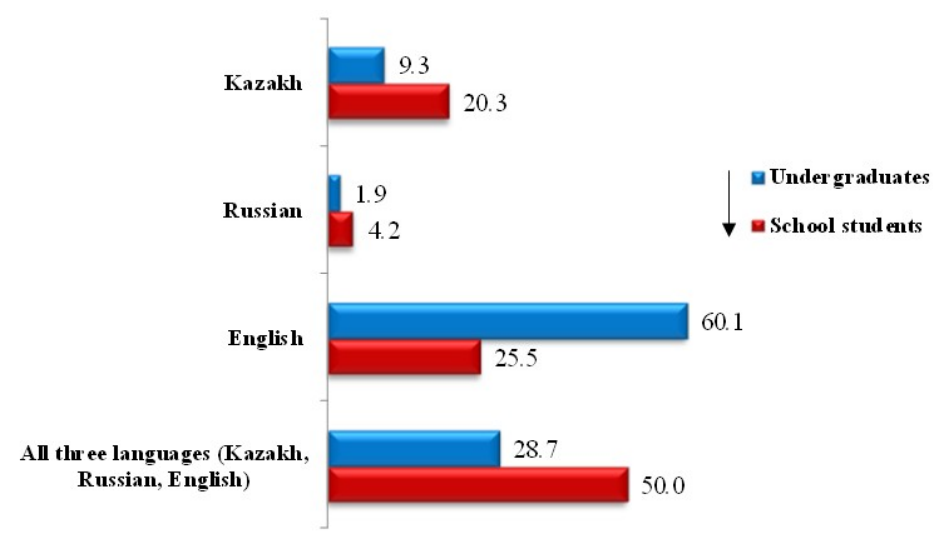

Figure 9. Distribution of the respondents' answers to the question: "Which of these languages do you think you can successfully learn by means of e-learning?"

As for the language preference, the general opinion divided among undergraduates and school students.

Undergraduates have chosen English as the most preferable among Kazakh and Russian to study by means of e-learning. As for school students they have chosen two languages to study with the help of e-learning: English $25.5 \%$ and Kazakh $-20.3 \%$.

\section{Conclusion}

In a multilingual process the role of the State and official language is of a great importance. All the citizens of the republic should master Kazakh as the state language. It should become the dominant one and gradually develop into a tool of communication among different ethnic groups

The Russian diaspora has a strong metropolitan country just across the border that produces a stream of cultural products in Russian. They are used by all Kazakhstanis, not only ethnic Russians. In the future the Russian language's status in the linguistic hierarchy will be lower than that of the state language but much higher than of any other language used by the ethnic groups (Koreans, Kurds, Turks, Germans, Tatars and others).

The topical problem of State Education Program of the Republic of Kazakhstan for 20112020 is to gain fluent mastery of three languages: Kazakh as the state language, Russian as the official and English as the language of International communication. As the result of the state program $100 \%$ of the population should speak Kazakh, $95 \%$ - Russian, $25 \%$ - English.

The results of sociolinguistic research conducted in the northern and southern regions show that Kazakhstani education has changed its policy in favor of multilingual education. The data of sociolinguistic research proved that Kazakhstani undergraduates and secondary school students would like to be taught in three languages: Kazakh, Russian and English and master these languages fluently. However, the opinion on language preference among undergraduates and school students is divided. Undergraduates outlined English as the most preferable language for education, while secondary school students gave their choice in favor of Kazakh and English. To have a complete understanding of the objective situation it is important to conduct sociolinguistic research the eastern and western regions of the country as well.

Study of the real situation with regard to multilingual education in Kazakhstan reveals that there are questions to be concerned and solved.

Respondents explain the use of old methodologies as one of the problems on the way to multilingual education.

Practice of using E-learning has becoming popular among young Kazakhstani generation. Most of them want to learn Kazakh, Russian and English through using E learning (83\% of undergraduates and 59.4\% of secondary school students).

The Kazakhstani education system has experience in the implementation of its multilingualism policy in institutions. It is important to introduce the most modern techniques into the multilingual training process for further development of Kazakhstani competitiveness in the sphere of education.

\section{References}

Agenstvo Respubliki Kazakhstan po statistike (ARK). (2000). Itogi perepisi naseleniia 1999 goda v Respublike 
Kazazhstan. Almaty.

Amalbekova, M. (2009). Phenomenon of bilingual personality in ethno-language landscape of Kazakhstan. Astana.

Arzoz, X. (2012). Bilingual higher education in the legal context: Group rights, state policies and globalization. Leiden, Boston: Martinus Nijhoff Publishers.

Babylon, \& Ontology. (n. d.). Multilingual and cognitive e-Learning Management System via PDA phone (BONy). Retrieved from http:// www.bonynetwork.eu

Bennet, M. (1998). Intercultural communication: A current perspective. Basic concepts of intercultural communication: Selected Readings. Yarmouth.

Caldwell, E. F. (2010). Bilinguals: Cognition, education and language processing. New York: Nova Science Publishers.

Commission of the European Communities. (2007). Final Report: High Level Group on Multilingualism Education and Culture.

Edwards, J. (1994). Multilingualism. London: Routledge. http://dx.doi.org/10.4324/9780203430927

Fierman, W. (2006). Language and Education in Post-Soviet Kazakhstan: Kazakh-Medium Instruction in Urban Schools. The Russian Review, 65, 98-116. http://dx.doi.org/10.1111/j.1467-9434.2005.00388.x

García, E. E., \& José, E. N. Sr. (2011). Bilingualism and cognition: Informing research, pedagogy and policy. American Psychological Association, Washington, DC.

Gosudarstvennaya programma razvitiya obrazovaniya Respubliki Kazahstan na 2011 - 2020 godyi: utv. Ukazom Prezidenta Respubliki Kazahstan ot 7 dekabrya 2010 goda, \#1118. (2010). Retrieved from http://ru.government.kz

Jankowski, H. (2012). Kazakh in contact with Russian in modern Kazakhstan. Turkic Languages, 16, 1. Harrassowitz Verlag. Wiesbaden.

Janpeisova, N. (2006). Representation of national stereotypes in the picture of world of Kazakh-Russian bilinguals. Aktobe.

Jikeyeva, A. (2011). Rechevoe povedenie zhitelej Kostanajskoj oblasti kak rezul'tat vzaimodejstvija russkogo i kazahskogo jazykov. Vestnik Cheljabinskogo gosudarstvennogo universiteta. Chelyabinsk, 25(240).

Kopylenko, M. (1997). Ethnolinguistics. Almaty.

Kubeev, E. K. et al. (2008). Koncepcija polijazychnogo obrazovanija. Karaganda: KarGU.

McLeod, Sharynne, \& Brian, A. G. (2012). Multilingual aspects of speech sound disorders in children. Multilingual Matters. Bristol; Buffalo.

Meyer, B., \& Birgit, A. (2010). Multilingualism at work: From policies to practices in public, medical and business settings. Amsterdam; Philadelphia: John Benjamins Pub. Co. http://dx.doi.org/10.1075/hsm.9

Ministry of Education of the Republic of Kazakhstan. Gosudarstvennaja programma razvitija tehnicheskogo $i$ professional'nogo obrazovanija $v$ Respublike. Retrieved from http://www.edu.gov.ru/kz

Parsons, T. (1975). Some theoretical considerations on the nature and trends of change of ethnicity. In N. Glazer, \& D. P. Moynihan (Eds.), Ethnicity, theory and experience. Cambridge, MA: Harvard Univ. Press.

Poslanie Prezidenta Respubliki Kazakhstan N. Nazarbaeva. Retrieved December 27, 2012, from http://www.akorda.kz

Stern, P. (1995). Why do people sacrifice for their nations? Political psychology, 16(2). http://dx.doi.org/10. $2307 / 3791830$

The resolution of the Government of Kazakhstan on February $3^{\text {rd }} 2004$ \# 128. Retrieved from http://tengrinews.kz/zakon

UNESCO. (2003). Education in a multilingual world. UNESCO Education Position Paper.

\section{Copyrights}

Copyright for this article is retained by the author(s), with first publication rights granted to the journal.

This is an open-access article distributed under the terms and conditions of the Creative Commons Attribution license (http://creativecommons.org/licenses/by/3.0/). 